\title{
FULL DISCLOSURE UNDER THE SECURITIES ACT
}

\author{
Brunson MacChesnet* aNd Robert H. O'BrIEN
}

The Securities Act of 1933 was passed to correct some of the abuses that had arisen in the distribution of securities. The popular name, the "Truth in Securities Act," aptly characterizes its essential purpose. The Congressional mandate embodied in the Act calls for full disclosure of many more facts than were normally revealed to the investor. The validity of this mandate will in large part be determined by the wisdom with which the Securities and Exchange Commission administers its provisions.

All persons seeking to use the mails or means of interstate commerce for the disposition of securities must file a registration statement with the Commission. A prospectus based on the registration statement must be given to the investor prior to any offer of sale. The Act authorizes the Commission to adopt rules and regulations governing registration statements and prospectuses for various classes of securities and issuers. These rules and regulations prescribe the form or forms in which the required information shall be set forth, and methods to be followed in the preparation of financial statements and reports or valuations by experts. The information required to be furnished in these documents is guided by Schedule $A$ of the Act, which sets forth the type of disclosure envisaged by Congress.

All the forms rest fundamentally upon Schedule $A$ of the Act. The emphasis of the form with respect to the information sought varies with the type of business, or nature of the security, or the circumstances surrounding the issuance of the particular security. While the requirements vary somewhat from form to form, what is said of any particular form is accurate to a large degree as to all forms. To reduce the area of discussion, comments on the forms and instances of disclosure will be confined to Forms A-I and A-2. These forms have made available information which prior to the Act was unavailable except incompletely in letters to stockholders, yearly reports and financial manuals.

Form A-I is used for the most part by companies in the so-called promotion stage.

- B.A., Yale University, 1931; J.D., University of Michigan, 1934. Member of Illinois Bar. Associate Professor, University of California School of Jurisprudence. Legal Secretary, Commissioner J. M. Landis, Securities and Exchange Commission, 1934-35. Author of The Securities Act and the Promoter (1936) 25 California IAw Revew, 66.

+LL.B., University of Chicago, I932. Member of Illinois Bar. Attorney, Registration Division, Securitics and Exchango Commission, 1934-1936. Now associated with Chapman \& Cutler, Attys., Chicogo, Illinois. 
In the typical case, the issuer is without any significant history as a going concern. The form emphasizes consequently the disclosure of the nature of the physical property in connection with which activity is to be conducted, various costs and charges to be assessed against the proceeds from the sale of securities such as underwriting commissions and bonuses, payments to promoters, payments for property, and the plan of business operations. Form A-2, used by so-called seasoned companies, requires information somewhat comparable to that reflected in Form A-r, but the emphasis is shifted to the financial statements reflecting both the present status of the enterprise and the results of operations for several years prior to the filing date. The financial statements, essential for the use of A-2, furnish more adequate disclosure than some of the detailed data required in A-r. For this reason, the requirements for some of the items in A-2 have been relaxed. The financial information, together with the information in narrative form in response to the items, give a reasonably adequate aggregate of data from which the degree of probability of continuity of the same trend may be estimated.

It is true that to some extent the picture presented in a registration statement and prospectus is incomplete. Many of the imponderables, such as the background of world conditions, and the factor of personalities and managerial skill, are not called for in the forms. The information required covers only a relatively brief period of the business history prior to the date of filing and the status of the business as of that date. The registrant is not expected to make prophecies concerning the future. Indeed the Commission has issued stop orders where prophecies involved clear misstatements of matters of fact. But the basic data essential to the exercise of a sound judgment, apart from general business conditions, should enable the investor to project the chances of success of the venture and to reach a reasonably accurate conclusion as to the value of a given share.

The data and information supplied in the forms may not be entirely valid or trustworthy for one of several reasons. The issuer may misconceive the meaning either of a particular word or a particular item. The misconception may result in either a minor technical deficiency or it may operate to dislocate the symmetry and the integration of the internal structure of the registration statement. Presumably, a person need give no information beyond that required by the form on which the particular securities are registered, except as procedural sections of the Act, prohibiting the omission of any statement without which the statements made are misleading, may create such an obligation. That is, one might give all the information required by the form and yet not have satisfied the requirement of full and fair disclosure. The effect of this is not merely to insist that each item as answered state the full truth, but that all the items answered fully in this sense must not give a misleading picture of the enterprise as a whole.

This is strikingly illustrated in the National Educators ${ }^{1}$ case. The filing of amendments to correct deficiencies in the answers to individual items led the Com-

${ }^{1}$ I S. E. C. 208 (1935). 
mission to discuss its power to challenge a filing because it was misleading as a whole. The Commission in its opinion wrote:

". . . As we have said before, our powers do not extend to preventing the public offering of a security if the truth concerning it be told, but the truth, under the Congressional mandate embodied in the Act, means the full truth. (CF. In the Matter of Plymouth Consolidated Gold Mines, Inc., r S. E. C. 139, June 1, 1935). The registration statement seeks to ascertain certain very definite particulars of a registrant. In many instances, answers to these may be technically adequate when viewed item by item. The combination of these items, especially those required to be set forth in the prospectus, generally reveal the character of the offering being made and the nature of the security the investor is being solicited to buy. But it may frequently be true that the cumulative effect of these individual items is carefully and intentionally concealed by their segregation in the prospectus, with the result that the impression left upon the reader by the prospectus is fundamentally untrue and misleading. The challenge of the Commission can thus under the Act be not only to individual items in the registration statement and prospectus as such, but upon the broad basis that the general effect of the prospectus as an entirety is to create an untrue and misleading picture in the minds of prospective investors. Frequently the prospectus, which is and should be a selling document, attempts to summarize in broad terms the nature of the offering. If this summarization is untrue, it can undoubtedly be challenged by the Commission. But even where there is no such summarization, the circumstances of a particular offering may well be such as to make the absence of statements setting forth in simple language the consequences of certain features of the financial structure of the registrant have the effect of portraying an essentially inadequate and misleading picture to the investor."

This opinion makes explicit the mandate implicit in the Act that the whole truth should be told. No subtle distinctions ought to avoid the clear necessity that those seeking other people's money should be completely frank about the enterprise in which the investor is urged to participate. Protection of the investor to this extent is certainly a minimum under the Act. Will such protection of the investor succeed in partially solving the problem of control of abuses of security distribution? The Commission in its administration of these provisons of the Act looking to full disclosure has developed techniques and policies which bear promise of success. Their significance becomes clearer in relation to their development. This development is best illustrated piecemeal. After something of a "Cook's Tour," we may be better able to gauge the extent of the new protection the investor is receiving.

\section{I}

\section{Promoters}

The promoter has been a key figure in the development of the Commission's policy as to full disclosure. The large number of small enterprises in the mining and brewery industries that have commenced business since the passage of the Act has led to fuller adumbration of the ambit of the statute as a by-product of dealing with the problems raised by their registrations. Much that has been decided will be of value when larger businesses of different types seek new funds. These latter 
enterprises have largely engaged in refunding operations, and are usually able to come within the requirements for the use of Form A-2. Payments to promoters are not of such great significance in this type of enterprise, and the form itself cannot be used if prior promotion payments have been excessive. ${ }^{2}$

In a new corporation, on the other hand, the share of the promoter is of special interest and significance as the percentage of dilution of the stock for promotional payments is apt to be great. Form A-I is designed to force disclosure of the promotion process so that the investor may know what he is paying for this type of service. The form when answered properly will bring out the names and addresses of the promoters, the stock interest, whether beneficial or of record, payments to promaters and the nature of the consideration given therefor, a statement of the intention of such persons with respect to subscription to additional stock and the prices at which such subscriptions will be executed, and details of any property purchases already made from promoters and any property purchases to be made by use of the proceeds of the issue registered. The Commission has, in many instances, compelled the identification of certain payments ostensibly going to an individual not named as promoter, or disguised as a payment for tangible assets, as promotional payments. Administration has made these requirements of disclosure not merely formal. A superficial statement of what has been given and what has been received is not enough. The real character of the promotional operation must be clearly presented. This insistence on reality is present both in the cases decided without opinions as well as those in which an opinion has been published. The opinions, however, make clear the basis for the other rulings.

To date, the Commission has made no definitive statement of the type of participation or activity which will render one a promoter. The accretion of its rulings in this connection indicates quite definitely, however, that its concept of "promoter" does not vary significantly from the common law doctrine. It may be said without attempting to predict possible extensions of the rule that one who participates actively in bringing about the formation of a corporation or one who participates actively in the launching of the enterprise after its formation will be deemed to be a promoter.

The Commission has brought about the disclosure of promotional payments, originally suppressed in the registration statement, by finding persons not named as promoters to be promoters. Payments to them are, therefore, payments to promoters and fall within the scope of the item seeking to elicit information concerning payments to such persons. Thus, in the Continental Distillers case, ${ }^{3}$ the chief promoter's law partner collected a commission on the sale of the property to the registrant. The Commission held he was a promoter and should have been named as such. In the Gold Hill case, ${ }^{4} 300,000$ shares were issued to one man for promotional services. The omission to name this man as a promoter was held a material omission. It

\footnotetext{
'One of the rules for its use denies the privilege to one otherwise entitled if promotional payments within a certain period prior to filing have been in excess of a certain amount.

r S. E. C. 5.4 (1935).

'Sccuritics Act Release No. 1036, Scpt. 16, 1936.
} 
should be noted that this item calls not only for payments for promotion service per se but for payments of any character to promoters. The crux of the requirement is to identify precisely the character of the payment so that the investor may know what amount the promoter has received purely for promotional services, as well as identifying payments of other amounts in different transactions.

In the Snow-Point Mining case ${ }^{5}$ certain persons who acted as promoters of the issuer were not named as such. The Commission held a hearing in the matter and wrote an opinion embodying its findings of fact on the evidence. The evidence showed that an item on the balance sheet in the amount of $\$ 260,000$ represented by 260,000 shares of stock of par value of $\$ 1.00$ and designated as promotional services, was due, not, as stated, to the only person named as promoter, but to four individuals, all of whom participated in the promotion of the registrant. The shares were allocated to these persons, not on the basis of a fair appraised value of the services rendered, but in accordance with a preincorporation agreement made between the four individuals, promoters, providing for a division of the authorized shares of the corporation to be formed. The Commission found in this case that the statement that $\$ 260,000$ represented payment for promotional services was false in the light of the origin of this figure in the preincorporation agreement. It was quite clear from the evidence adduced at the hearing that promotional services of that value were not rendered and that the promoters, who, subsequently, acting as a board of directors, adopted resolutions awarding themselves these shares, made no bona fide finding that promotional services of any particular value were performed in behalf of the corporation. Their primary purpose was to obtain control of the company.

This same disregard of the future investor is illustrated by the opinion in Matter of Franco. ${ }^{6}$ The promoters in that case admitted the stock was issued in accordance with a preincorporation agreement. They represented that the consideration for the issuance of 150,000 shares with "stated value" of ten cents a share was the transfer of a lease-purchase agreement, which testimony at the hearing disclosed had been acquired by the promoters for no consideration. The Commission held that the omission to disclose this information called for by the form, as well as the representation of "stated value," was misleading.

A case which illustrates strikingly the adept handling of literal statements descriptive of payments to promoters, which through lack of precision and identification create a misleading picture, is the opinion of the Commission in the Brandywine Brewing Company case. ${ }^{7}$ The statement as originally filed recorded on the balance sheet the item "property \$roo,000." The Commission raised a question as to the truth of this $\$ 100,000$ valuation placed on the Brandywine property in the registrant's balance sheet as originally filed. As a result, the registrant filed an amendment to its registration statement containing a new balance sheet certified by a different firm of accountants and carrying the property at $\$ 29,000$, and promotional expense at
II S. E. C. 3 II (1936).
-I S. E. C. 285 (1936).
'I S. E. C. 123 (1935). 
$\$ 7 x, 000$. The truth of this balance sheet was put in issue at the hearing. The Commission, contending that the figure $\$ 71,000$ for promotional service involved primarily a representation that services fairly and reasonably worth that amount were rendered, reviewed the evidence concerning the extent and nature of the services rendered by the promoters and concluded that the item of $\$ 71,000$ in the balance sheet for promotional services constituted a misstatement of a material fact and held that a large portion of this stock was in reality donated to the promoters and not issued for services as stated, and should have been so identified.

Cases involving more brazen overvaluations clearly fall within this principle. Thus, in the Haddam Distillers case, ${ }^{8}$ the valuations were admitted to have been padded in order to disguise promotion payments. This same device was attempted in the Unity Gold case. ${ }^{9}$ In Continental Distillers, ${ }^{10}$ a promise on the part of promoters to spend $\$ 50,000$ in improvements, the binding character of the promise being far from clear, was included in the "cost" of property. In the Plymouth Gold Mine case, $^{\text {i1 }}$ an omission to disclose that the president, the chief promoter, had bought the property at a tax sale, was misleading, as it is this contrast between cost and valuation which is so illuminating to the investor. Similarly in La Luz Mining, ${ }^{12}$ the promoters did not reveal the consideration they paid for the stock of another corporation which they exchanged for stock of the registrant. The failure to disclose preincorporation agreements in Franco Mining ${ }^{13}$ and Snow-Point Mining ${ }^{14}$ has already been noted. In the Great Dike Mining case, ${ }^{15}$ the statement that a lease and option agreement was the consideration for the stock issued to promoters was untrue. The hearing showed that the lease and option had been acquired by the promoters at no cost to themselves, as in Matter of Franco. ${ }^{16}$ In the recent case of Mining and Development Corporation, ${ }^{17}$ the promoters attempted to include cash advances, previously made, as part of the cost of property sold by them to their corporation.

Frequently, the presentation of the present status of a registrant and its history is complicated by the fact that formal action to a certain end will have been taken by the issuer's board of directors in connection with the value to be placed upon assets and the consideration received by the corporation in exchange for issuance of shares of stock. In several of the cases just discussed this was the method used to disguise promotional payments. Should the Commission allow this formal action to serve as a screen for such payments? The courts of many states hold that the action of a board of directors in placing a value upon particular assets of the corporation, in the absence of bad faith or fraud, will insulate against successful actions by creditors or stockholders based upon stock watering theories of liability. The Commission, however, accepts statements concerning action by the board of directors

\footnotetext{
${ }^{20}$ Supra note 3 .

18 I S. E. C. 217 (1935).

14 Supra note 5 .

${ }^{15}$ Supra note 6.
}

I S. E. C. 37 (1934); I S. E. C. 48 (1935).

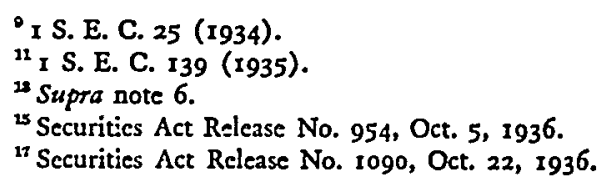


only to the extenit that they purport to reflect that the board of directors as a matter of form has made the pronouncements and reached the conclusions expressed in the resolution, but refuses to accept the statements as establishing the truth of the conclusions stated.

The Unity Gold case ${ }^{18}$ presented this issue squarely. A lease and option on mining property was transferred by one corporation of the promoters to the Unity Gold Corporation in exchange for $\$ 5,000$ cash and 599,995 shares of common stock, par value \$I per share. 475,000 of these shares were immediately "donated" back to Unity Gold's treasury, pursuant to agreement. The purpose of this transaction was to make these "donated" shares valid treasury shares which could be sold at less than par as non-assessable stock. But these shares were included by the promoterdirectors as part of the cost of the lease and option. The Commission challenged the inclusion of such "donated" shares as part of the cost. Despite the validity of this device to make the shares fully paid and non-assessable in the state where this corporation was chartered, the Commission held that, "under the standards of truthfuilness demanded by the Securities Act," their inclusion as part of cost was untrue and misleading. ${ }^{19}$ The effect of this decision was not only a more truthful statement of cost but the elimination of a fictitious surplus from the balance sheet.

This same policy of penetrating the veil of directors' motions has been pursued in other cases. In Continental Distillers ${ }^{20}$ the valuation of the property as equivalent to the stock issued to the promoters was challenged when this valuation was greatly in excess of the price paid in a recent transfer. In American Gyro ${ }^{21}$ the directors had arbitrarily valued an untried invention as worth \$260,000 in "good will," although good will is clearly misapplied in such a case. In Mining and Development Corporation, ${ }^{22}$ the Commission, after finding that the first alleged basis of valuation was invalid, held that an amendment, made with knowledge of such invalidity, that retained the same figure with a footnote stating it was not present value was still untrue and misleading.

Another aspect of the Commission's treatment of promotion problems is the compelling of disclosure of various selling schemes. In Gold Producers, ${ }^{23}$ the representation that the stock was being given away to investors, when the stock was assessable, was held untrue. In Plymouth Gold Mines ${ }^{24}$ the promoters made a similar appeal to the bargain-hunting instincts of the investor. The investor was led to believe that the payment of an additional small sum would salvage his original investment with the same promoters. The Commission held that a price of stock, which included the worthless old shares as a substantial part, was misleading. A "chain selling" scheme was the device of the promoters in the Wee Investors case. ${ }^{25}$

is Supra note 9 .

${ }^{2}$ It will be noticed that the misleading consequences of this entry are reflected by the contra entries necessarily made to Capital Surplus.

2 Supra note 3 .

.2 Supra note 17.

"Supra note II.

${ }^{2 t}$ I S. E. C. 83 (1935).

$\approx$ I S. E. C. I (1933).

${ }_{1}^{2}$ S. E. C. 202 (1935). 
The Commission held that it was misleading in the absence of disclosure that only a few out of many potential investors could profit in the manner alleged.

The investor was courted by a "stockholders' protective plan" in the Oil Ridge Oil and Refining case. ${ }^{26}$ The promoters claimed that thirty percent of the investment would be withheld from the oil venture and invested by the promoters so as to equal the original principal at the end of twenty years. At the end of this time, the investor could elect between the result of his oil venture and his "investment." The Commission pointed out that the investor himself.could match his own investment in a similar ratio and not have to elect between them at the end of the period. To characterize this as a protective plan having a "bond" feature and "guaranteeing" the principal was held grossly misleading.

The selling device of a "step-up" in price, which enables the salesman to urge the investor to get in before it is too late, was employed in the Snow-Point ${ }^{27}$ and Avocalon. Extension ${ }^{28}$ cases. The Commission found in both instances that the "step-up" had no relation to increases in value of properties behind the stock, and that the arbitrary increases were, therefore, misleading.

This discussion of the promoter illustrates the method of the Commission. The emphasis is on identification of the charges for promotion so that the investor may judge their worth. To disclose these charges, the various elements serving as a basis for comparison must be marked for what they are.

\section{II •}

\section{UNDERWRITERS}

A similar emphasis on proper identification of the underlying elemients in the investment picture marks those portions of the registration forms relating to underwriting and distribution. Copies of underwriting contracts must be filed with the registration statement as exhibits, but the Commission intends these more for the use of its own trained examining staff than for the perusal of investors: they are not required to form part of the prospectus. Here as elsewhere, the Commission recognizes that the sheer length of carefully drafted financial documents discourages the average investor from reading and understanding them. Hence the registration form includes items requiring a brief but explicit summary of the salient features of the arrangements for distribution, and in the examination process their adequacy is checked against the documents themselves. These items demand a statement of the price at which the underwriter is to take the securities, the price or prices at which he proposes to sell them to the public, together with full details of his own profit and of the participations he will allot to distributors and "finders." If preferred lists exist, the form will show their existence and nature, unless there is deliberate concealment or misstatement, for one item requires identification of those to whom the securities may be offered at any price varying from that at which the

* I S. E. C. 225 (1935).

"Supre note 5.

- Securities Act Release No. 1005, Aug. 26, 1936. 
public is invited to buy them. Other items, asking that all persons affiliated with the management indicate whether and at what price they intend to subscribe to the securities, supplement the disclosure of preferred lists on Form A-r and at the same time may give the investor some indication of the confidence which the moving persons in the enterprise repose in it.

Where such insiders already possess substantial blocks of securities of the same class as those being registered, the Commission exercises an especial vigilance to insure the investor against undisclosed distortion of the market at the time of flotation. Thus, the Commission insists that the prospectus reveal the existence, and a summary of the terms, of any agreements restricting or preventing the sale or disposition during the distribution period of securities of the same class as those underwritten. This type of agreement, commonly characterized and referred to as a "stand-off," operates to diminish the supply of the particular securities at the exact time an intensive effort is being made to stimulate demand and puts the underwriter in position of regulator. The probable effect on the price is quite obvious. Similarly, when securities are stated to be offered at "the market," the issuer is required to state what market is meant and give a description of the nature of the market involved and the extent of his own activity or the activity of underwriters or dealers in such market. ${ }^{28}$ The position of the underwriter is thus clearly revealed.

\section{III}

\section{A. Experts}

\section{Persons ReLATEd to the Issuer}

The development of the Commission's rulings in connection with experts has been a most interesting one. There have been two distinct lines of inquiry. One has been the disclosure of the interest of the expert in the issuer, and, as a corollary thereof, the "independence" of such an expert in the situations where independence is required. The other development has been one of testing the methods employed and results attained by experts, and even delineating the minimum standards necessary for that status.

(I) "Interest" and "Independence"

The forms are so designed that the validity of the information supplied or the reliability of any expression of opinion contained in a registration statement may be appraised with knowledge of the existence of an interest of any expert on whose authority such statements are made or any interest of an expert whose statements or expressions of opinion are used in connection with the registration statement or prospectus. Likewise, the integrity of any transaction may be estimated with knowledge of an existence of a colorable relationship by a participant in such transaction with the registrant. The Act itself requires that the financial statements shall be certified by an independent public accountant. The theory of the Act is that an

See, in this connection, Section 9 of the Securities Exchange Act of 1934 . 
investor should not be left to rely on the conscience of an accountant preparing the financial statements, but should have at least the expression of his judgment without the color of an interest in the aims and progress of the issuer.

The opinion of the Commission in the Plymouth Consolidated Gold Mines, Ltd., case $^{30}$ illustrates the type of relationship or anticipated relationship which the Commission deems to be an interest of an expert in the issuer which should be disclosed in the registration statement and prospectus. In that case, the registration statement contained a report by a mining engineer. The evidence at the hearing disclosed that this particular engineer was hopeful of obtaining employment with the issuer when its mines were put in operation, and showed further that at the time of making his report this engineer was general manager of the properties of a predecessor during a former period of operations. The Commission held that the inclusion of these facts came within the general ambit of disclosure called for by the item. ${ }^{31}$

The question of independence was presented squarely in the stop order proceedings relating to Cornucopia Gold Mines. ${ }^{32}$ The financial statements in that instance were certified by a person who was an employee of the firm of accountants certifying to the financial statements, but he likewise acted as comptroller for the registrant under the terms of a contract between the registrant and the accounting firm. It was conceded that the financial statements truthfully and accurately reflected the status of the issuer, the only issue being the independence of the certifying accountant. The Commission reviewed the evidence which showed, among other things, that the accountant whose independence was in issue received no salary from the registrant but received his remuneration entirely from the firm of accountants. It was established, however, that, at the time the registration statement became effective, he was exercising the usual functions of a comptroller with authority over registrant's employees regarding accounting matters, signing mail of the issuer and also having authority to sign checks with another officer. The evidence further disclosed that he owned 1,760 shares of stock of the issuer which he had paid for with cash prior to the filing of the registration statement. ${ }^{33}$ The Commission concluded that it was unreasonable to suppose that the accountant under these circumstances would cast aside these relationships and view the accounting principles with the objectivity of an "independent" accountant, criticizing and correcting accounting practices and methods of the corporation's own staff. In making an audit, he would be in fact reviewing his own work. It was held that the existence of these disabilities prevented

Supra note $\mathrm{I}$.

"In the Great Dike case, supra note 15, the accountant who certified the statements, except for receipts and disbursements, was employed on a contingent fee basis. He admitted that his methods and results were not to be relied upon.

I S. E. C. 364 (1936). It was also held in this case that the failure to disclose the interest was an omission under Item 50-an omission of the type discussed in the text in connection with the Plymouth case, supra note 30 .

The mere existence of an interest does not destroy independence. The Commission said in its opinion in the instant case "A continuing pecuniary interest which an accountant has in a registrant may be so small or so indirect as to give rise to no inference that the accountant has lost or is likely to lose that objectivity which is implicit in the concept of an "independent" accountant. 
him from being an independent accountant. As the company had filed amendments subsequent to the date of initiation of stop order proceedings, including financial statements certified by an accountant admittedly independent, the Commission, as it may within its discretion, dismissed the proceedings without issuing an order.

The demand for independence is even more clearly illustrated in the recent opinion in the American Terminal and Transit ${ }^{34}$ case. The accountant in that case, despite certification, which the Commission had held in the Cornucopi ${ }^{35}$ case to be a material fact, had recorded in the balance sheet as cash an item that was an overdraft on the books of the company. The Commission found this to be an untrue statement of a material fact. This falsification, however, led the Commission to find that an inference of absence of independence should be drawn. The opinion pointed out that there was no relationship of the type discussed in the Cornucopia case, but that the standards of the Securities Act demanded that "independent" experts approach their task with complete objectivity free of any entangling alliances, and that falsification of this type, for whatever motive, destroyed the basis for an inference of independence.

(2) Standards and Qualifications

The Commission, as has been stated, has not only insisted on disclosure of the interest of an expert and real independence when independence was required, but it has also gradually delineated the standards, methods and integrity necessary for one to hold himself out as an expert.

It is patent that all the information in the registration statement cannot be based upon expert opinion or knowledge. The determination of what information may be given upon the authority of an expert and what information must be supplied by the issuer itself is a matter of day-to-day routine of examination of registration statements. Assuming that the subject matter covered by the expert is of a type or kind properly susceptible of treatment by an expert, what are the standards set up by the Commission by which the validity and accuracy of the expert's conclusions will be tested? The Commission in the Haddam case ${ }^{36}$ stated that valuations contained in an appraisal purporting to follow certain norms are representations that these norms have been accurately and fairly followed. If the norms purported to have been followed are not fairly observed, the valuations finally arrived at are in essence misrepresentations of fact because they untruthfully describe the basis upon which the valuations are made. In Big Wedge Gold Mining ${ }^{37}$ the Commission held that a mining engineer's report on ore bodies which neglected fundamental principles of scientific method and disregarded obvious and known facts and also disregarded the standards he expressly or impliedly purported to follow constituted a misrepresentation of fact. Thus it becomes clear that the Commission will, in connection with any report prepared by an expert, insist that the conclusions ex-

\footnotetext{
" Securities Act Release No. 1066, Sept. 29, 1936.

\$supra note 32 . $\$$ Supra note 8.
}

${ }^{57}$ I S. E. C. 98 (1935). 
pressed in the report be based upon an exercise of technique and procedure common among the class of experts with which he identifies himself. It will be noted that in both these cases the Commission criticized the report on the ground that the method impliedly followed in reaching conclusions had not, in actuality, been followed. The Commission's action in these two cases represented a challenge of both the method and result of the appraisals.

A variation of the Commission's action with respect to experts is represented by its opinion in the La Luz Mining Corporation proceeding. ${ }^{38}$ The registration statement included a report by one Professor Haas, describied by registrant as a scientist and geologist of world-wide renown, and the inventor of the "mineral indicator." While no thoroughgoing description of the mineral indicator was set forth in the registration statement, it turned out at the hearing subsequently called that the mineral indicator was a cylinder suspended from a leather thong, by which the professor claimed to be able, with uncanny accuracy and precision, to estimate the length, depth, width and average value of mineral veins. It appeared that the professor had been a horticulturist until ten years before the date of the hearing, at which time he discovered and constructed his mineral indicator. Two expert witnesses produced by the Government. testified that the professor's mineral indicator fell within the class of devices known as "doodle bugs," and both were quite positive that this method of prospecting for ore-bodies was ridiculous. The Commission, in its opinion, characterized the method as ludicrous, but did not pass upon the qualifications of Professor Haas in the matters in which he was held out as an expert. There was no room for criticism of Mr. Haas for deviation in application of recognized "mineral indicator" principles as Mr. Haas, being discoverer of this method of locating and evaluating ore bodies, unquestionably adhered to the standards of his own creation.

These three opinions taken together establish that the conclusions of value reached by an expert may be challenged by the Commission either because the method is unsound or because of failure to adhere to norms impliedly followed, or, aside from principle and method, because the result expressed is inaccurate. It is only inferentially that the Commission has, through these opinions, passed upon and expressed an opinion as to the qualifications required to be possessed by an individual before he may be held out as an expert.

In the recent case of Gilpin Eureka Consolidated Mines, ${ }^{30}$ the Commission made explicit the necessity that an expert have the normal skill of his profession and follow the procedures usually employed. The prospectus in that case stated that the president had been an engineer for the Austrian Government for four years, and that he had been, for the last three years, engaged in mining engineering. The evidence disclosed that his Austrian experience consisted of driving and overhauling locomotives for the government-owned railroad, and that his mining training ranged

* Supre note 12.

- Securities Act Release No: 1078, Oct. 13, 1936. 
from the reading of textbooks to conversation with mining people. The Commission, therefore, held that these representations of expertness were misleading, and in its opinion said:

"The qualifications which characterize the expert are not rigid and categorical. Certainly training, integrity, intelligence and experience are among them. We do not attempt to present a precise scale for the measurement of these qualifications. It is equally certain, however, that one truly an expert brings to his work knowledge and skill which are the substance of his profession and which are evinced by his use of the principles and procedures normal to others in his field, and we can and do take the position that by the failure to employ such normal principles and procedures the absenic of the requisite knowledge and skill is disclosed."

\section{B. Insiders, Directly or Indirectly Related to Issuer}

The items of the forms are so correlated and integrated that, assuming accurate and complete answers, past uses of the issuer's assets to the direct or indirect benefit of the insiders will be shown. The story may become evident from the answer to a single item or from the combined answers to several items. Ordinarily, examination technique forces disclosure of motives of self-profit and unusual payment through the citation of deficiencies on issuer's statement of the business done and intended to be done, the statement of underwriting commissions and other expenses incurred or to be incurred in the course of the sale of the issue, the uses to which the proceeds are proposed to be put, property púrchases already made and those to be made out of the proceeds of the issuer, the statement of stock ownership which discloses sources of control not evident from the formal statement of the directorate, and management and promotional payments.

An interesting illustration of the exercise of administrative powers to bring about disclosure of facts originally concealed or misstated is the Commission's opinion in the American Gyro Company case. ${ }^{40}$ It was represented in the registration statement that the company was organized for the purpose of conducting experimental work in connection with certain inventions, particularly in development and construction of a so-called gyro-plane. One H. M. Little was shown to be in control of registrant and to have been the dominating figure in all its financial operations and in its management. The evidence at the hearing established that Mr. Little was likewise the promoter and dominant person in a company engaged in the printing business and a company engaged in gold mining and in a third company organized for the coal and coke business, whether or not it was actually engaged in it. The Commission found among other things that "The registration statement not only failed to make the specific disclosures set out in the trial examiner's report to show that moneys coming into the registrant's possession were not being applied in accordance with representations, but it failed completely to show that these uses of the finances of the company for purposes other than those represented in the

- I S. E. C. 83 (1935). 
registration statement were actually for the benefit of Little, who was one of the promoters of the company."

\section{Management and Control}

Disclosure urider this head emphasizes information hitherto all too frequently slighted. The stock-holdings, not only of the official management, but of those who may exercise real control through stock ownership, are demanded. The interest of such persons in property acquired within two years or to be acquired must be revealed. The remuneration of directors, principal officers, and other "insiders," management and supervisory contracts, the names and addresses of directors and officers, and a brief description of the business experience of the principal officers during the last five years complete the requirements in A-2.

In the American Credit Corporation case, ${ }^{41}$ the registrant stated that "the character and history of the management should assure the success of the company." The evidence at the stop-order proceeding, however, would convince even the credulous that this was something less than a mild overestimate of their own ability. The chief promoter was one Henry Girola, who had been the principal figure in other investment companies. The facts were that these investment companies had gone into receivership and bankruptcy, and their earnings statements were falsely compiled, losses being shown as investments and operating expenses added to cost of stock of subsidiaries. While in such condition, sales literature misrepresenting the status of one prior company caused the Corporation Commission of California to revoke the permit to sell. Representatives of the California Corporation Commission testified that no permit to sell would be issued to any company under the management of Mr. Girola. The prospect of such management as Mr. Girola had furnished in the past was not reassuring. To state that such management promised success was obviously misleading.

The best evidence of the caliber of management does not often arise so directly. The matters dealt with in this paper under other headings speak volumes on the character of management the investor will receive. Lengthy statements on the character of the management would serve no purpose. Failure to live up to the standards of a fiduciary, an obligation which the solicitation of other people's money implies, carries-its own condemnation.

\section{$\mathrm{V}$}

\section{Disposittion of the Proceeds}

All the forms require the detailed statement of the purposes to which the proceeds of the issue registered will be devoted and the approximate amount for each such purpose. In the case of established businesses, the issue registered is being sold for the purpose of obtaining funds for working capital and a detailed break-down is

2 I S. E. C. 230 (1935). 
frequently impossible. However, in these instances, the availability of other information in the registration statement, descriptive of the nature of past operations, and the probability of continuity of operations of the same character should enable the analyst to determine with fair accuracy the general uses for the proceeds. In 2 new enterprise the proposed use of the proceeds is of greater significance. The examination technique in this connection is to cite the deficiencies in every statement in which information concerning the proposed uses of the proceeds is not correlated to and integrated with the statements concerning the nature of the business done and intended to be done. Invariably, the registrant is required to describe the plan of business operations if the statement of uses of the proceeds is based upon any considered plan of operations. The break-down into detail of separate purposes is not only required but the Commission's technical experts check the adequacy of the separate amounts stated for each purpose. Thus, in the American Kid Company case, ${ }^{22}$ it was stated that $\$ 100,000$, out of $\$ 450,000$ to be raised, was to be used for working capital. This was shown to be out of line with the experience of the industry. Even though amendments revealed an intention to supplement this amount by the use of letters of credit, which would be prior to the securities, the Commission held it to be misleading in the absence of explanation to record estimates materially out of line with the industry. The various estimates for costs were likewise out of line with similar conditions in the industry and so were held misleading when not justified.

The registrant is required to state the priority of application of the proceeds to each individual purpose, and, if the plan is one which can be successful only if the entire amount be raised, the registrant is required to make such a statement and a declaration of its intention with respect to disposition of the proceeds in such event.

Certain registrants have attempted, by giving a thorough-going detailed answer to Item 27, to create the picture of a thriving prosperous enterprise. However, details can be overdone-and can mislead rather than inform. The Commission requires only such information as the registrant is in a fair position to furnish, and, if the registrant is secking an amount of money from the public, a portion of which it has no present need for and does not know what to do with, the truth of the situation requires that it say so. Thus, in the stop-order proceeding relating to Gold Shore Mines, L\&d., ${ }^{43}$ the trial examiner found that the statement concerning proposed uses of the proceeds of the issue was misleading in its representation that the registrant was in a position to predict the uses of the proceeds, whereas it was actually in no such position. The facts showed that the issuer was a recently organized mining company which owned an extensive area along the shores of Lake Winnipeg, Canada. The issuer proposed to explore for commercial gold and develop whatever deposits might be encountered. The evidence at the hearing showed that only a slight amount of exploration work, consisting of a few shallow

\footnotetext{
'Securities Act Release No. 1061, Oct. I, 1936.

- No Commission opinion was written.
} 
surface pits and cuts at irregular intervals along the course of the vein, had so far been completed. Expert testimony was introduced to the end that no mining engineer could, in view of the undeveloped character of the property, so perfectly and precisely allocate definite sums to particular purposes."

The registrant subsequently amended its statement in a manner to make clear that an amount of money far in excess of the issuer's present needs was being raised, and to disclose that possibly the entire amount would never be needed, as the initial exploratory work might not result in the discovery of any commercial ore bodies. The issuer likewise stated in its amended statement its proposal with respect to the disposition of the remaining proceeds assuming unfavorable results from the exploration work.

This same omission to disclose the possibilities and effects of failure upon the disposition of the proceeds is further developed in the Mining and Development case. ${ }^{45}$ The promoters in that case had an interest in a Bolivian mine. They obscured the export and exchange restrictions obtaining in Bolivia which vitally affected their estimate of profits, as well as casting doubt on the possibility of operating the mine at all. Furthermore, the status of litigation with respect to the Bolivian property was such that the registrant might have no interest at all, or, if they did have an interest, it might be only as a lessor for some years. In connection with another property, the promoters did not disclose that sufficient proceeds had to be raised to pay off their own prior claim before the property became available for operations.

The misleading character of excessive detail as to use of proceeds when such certainty is not possible, noted in the Gold Shore Mine case, ${ }^{40}$ was likewise challenged in the Snow-Point Mining case. ${ }^{47}$ But general statements as to intended use when details should and could be furnished are likewise misleading. Thus, in the Lewis American Airways case, ${ }^{18}$ the Commission held that the registrant, in answer to the item, must disclose some program from which the investor may judge the investment possibilities.

\section{VI}

\section{Capitaluzation}

The items relating to the capitalization of the registrant are designed to make clear the rights that the investor will acquire. In Form A-I this is less thoroughly developed. The rate of dividend and method of payment in the past, the present

4The expenditure of the $\$ 600,000$ net proceeds (except for certain sums for selling expenses) to be derived by issuer from the sale of the securities, was provided for as follows: $\$ 4,000$, Construction of camps; \$24,070, Diamond drilling; \$25,500, Exploration power plant; \$ro,500, Mine office and salaries of certain employees; $\$ 50,000$, Exploration in the way of shaft sinking and drifting and cross-cutting; \$125,000, Equipment for a 200-ton mill; \$ro,000, Construction of a mill building; \$18,000, Freight charges; \$25,000, Transformer station; \$75,000, Power line; \$22,000, Miscellaneous; \$102,000, Work in connection with the preparation of mine for production; \$155,000, Additional power equipment and camp accommodation.

${ }^{45}$ Supra note $17 . \quad$. $\quad$ "Supra note 43.

"Supra note 5 .

${ }_{15}$ S. E. C. $330(1936)$. 
capital set-up, the kind of stock to be issued, including information on par or stated value, and price per share, and, for each class of stock, the voting rights, preferences, conversion, exchange rights, liquidation rights, and similar incidents, comprise the stock data. For bonds, the present debt structure, and as to bonds to be issued, the principal amount and offering price, and the provisions for additional issuance, type of amortization provision, the security for the debt, and priorities, and provisions for substitution including a statement if substitution is permissible without notice. For Form A-2, the information required on the incidents of the securities outstanding and to be issued is much more comprehensive. Thus, in the case of bonds, not only the data required in A-r, but more specific -description of the security for the debt and priorities, conditions affecting the obligation to pay interest, percentage of security holders required to move the trustee to action, provisions for modification, and inter-relationships of trustees, directors and officers, all help to complete the picture. In both forms, the balance sheet and income statement, with supporting schedules, are essential elements in furnishing the information on capitalization that the investor needs.

The balance sheet is the point at which misrepresentations and omissions of various types are, in many instances, reflected. An examination of the information given in response to the various items in the registration statement against the background of the information in the financial statements and schedules frequently reveals deficiencies either in the narrative information or the financial statements. Thus the narrative description of payments to promoters and the consideration therefor may disclose either the misapplication of accounting principles in reflecting such transactions on the balance sheet or a direct misstatement of what has occurred in the transaction as a matter of fact. For instançe, the registration statement proper calls for information concerning payments to promoters and the nature of the consideration received by the issuer in return therefor. The information in the statement may show that a variety of things was given the corporation by the promoter in exchange either for money or a block of stock, such as promotional services and property transfers. The whole transaction will, in many instances, be reflected on the balance sheet as an exchange for property exclusively. In those cases the Commission insists upon a breakdown of the property item to reflect more accurately and precisely the various things received by the corporation and the amount of stock from the block attributable to each as payment therefor. This has already been viewed with respect to the promoter in the discussion of the Snow Point Mining ${ }^{49}$ and other cases.

The examination technique in connection with financial statements and schedules frequently involves a blended application of principles of valuation and principles of accounting. An appraisal may give rise to a figure designated as surplus on the balance sheet. In some cases this surplus may carry no label permitting an exact identification of the origin and character thereof. If, as a matter of fact, the surplus

4. Supra note 5. 
is due to an appraisal of assets and is unrealized, the Commission insists upon a precise designation showing that it is of that nature. If there is reason to believe that the figure at which the assets are appraised is excessive, a detailed technical examination of the appraisal report is made, such examination being followed in a large number of cases by a physical inspection of the properties involved. Upon these bases the Commission may conclude that the figure is false, and that the surplus represented to exist is, in part or in whole, non-existent. For example, a registrant, engaged in the business of manufacturing novelty yarns from raw cotton, represented in its balance sheet that its plant, property and equipment had a value of $\$ 163,000$. The cost of the plant appeared to be $\$ 63,000$. A physical inspection of the properties was made, and as a result the registration statement was withdrawn.

In another registration the issuer was engaged in the manufacture of composition building materials and, in connection with its business, mined gypsum which was used as the basic ingredient in the product marketed. The gypsum deposits were carried on the balance sheet at an appraised value of \$2,753,299.24 in excess of cost. The appraisal, which had been made in 1928, was based on the volume of the deposit and the rate at which the gypsum would be mined. Seven years of experience in the conduct of the business established that the rate assumed by the appraisor was far in excess of that actually attained and, in all likelihood, was seriously in error in view of registrant's future prospects. The appraised figure gave rise to an item on the balance sheet entitled "Surplus Arising from Unrealized Appreciation of Assets" in the amount of $\$ 2,753,299.24$. The whole problem was further complicated by the fact that in 1932 , on the authority of both directors' and stockholders' resolutions, the company wrote down the deposits by $\$ 1,086,297.95$, and debited Unrealized Appreciation with a like amount, leaving a balance of \$1,667,001.29 in the latter account. This balance of unrealized appreciation was wiped out by writing off the cost of selling stock previously issued, charged off in 1926 and 1927 in the amount of $\$ 206,22 x .06$; original organization expenses charged off in 1926 in the amount of $\$ 27,86 \mathrm{r} .44$; market development charged off in 1928 in the amount of \$75,IIr.II; and the following items written off in 1932: Lands and buildings, machinery and equipment, mining development cost, mine stripping cost and appreciation charged to mining costs on tonnage basis prior to 1932. The Commission raised a question in connection with these financial statements both as to the validity of the amount carried as value of the gypsum deposits and the propriety of charging off against the resulting surplus all but one $e^{50}$ of the items listed above. The Commission took the position that it was improper and contrary to accepted accounting practice to combine unrealized appreciation with surplus directly, and likewise improper and misleading to use this account as a dumping ground for items which should be amortized against income.51 The effect of these devices was to relieve

${ }^{30}$ The exception was a charge of $\$ 6 \mathrm{I}, \mathrm{I} 64.08$, which had been made to appreciation charged to mining costs on tonnage basis prior to 1932 .

" A steel company created a reserve for plant retirements by charges to paid-in surplus and shortly thereafter, in 1932, wrote off properties retired in the amount of \$1.744.213.61, making the charge to 
surplus of certain charges and ta prevent the determination of the extent of the write-up remaining in the net assets. The problem was finally solved when the issuer included in an amended registration statement and prospectus two balance sheets, one as originally submitted based on the appraisal and the second based upon the cost of the physical assets, with appropriate explanations concerning the respective bases. The accountant in his certificate stated that the "cost" balance sheet reflected accepted accounting principles.

This same procedure of having two balance sheets, one representing the figures of the issuer, and the other in accord with accepted accounting principles, is found in a public utilities system registration. The balance sheet originally filed represented that this public utilities system had a capital surplus of approximately $\$$ III,000,000 and an earned surplus of approximately $\$ 12,000,000$. There were pages of footnotes appended to this balance sheet which revealed on close study that improper accounting and financial practices had been followed. The Commission required the registrant to present an adjusted balance sheet reflecting these practices which would serve for comparison with the original figures. The adjusted balance sheet revealed a corporate deficit of $\$ 30,000,000$, as well as a reduction of $\$ 153,000,000$ in the company's assets.

A variation of Commission treatment of financial statements is illustrated in the registration of another public utilities system. The company had written up its assets on the basis of an appraisal made by an affiliate. The unrealized appreciation thus created was then charged with unamortized bond discount and expense, which should have been amortized over the life of the bonds on which it was incurred. The effect of these methods was to overstate earnings over a period of years. The Commission required that the footnotes to the balance sheet indicate what earnings would have been if proper accounting practices had been followed.

The recent case of Mining and Development Corporation ${ }^{52}$ illustrates the adaptability and evolution of the administrative process. Some of the company's properties had been valued on a basis admittedly improper, and the registrant had filed an amendment eliminating this improper basis but retaining the same figure with a footnote warning that this figure did not represent present value. The Commission's holding that this figure could not stand has been discussed in connection with Promoters. But the Commission went on to deal with the argument that the footnote served to correct the untruth represented in the balance sheet:

this reserve. The facts in the case indicated that depreciation charges in previous years had been insufficient to provide for the normal retirement of the properties. The charge to the reserve created from paid-in surplus thus relieved the earned surplus of the charge. The accountant had failed in his certificate to express an opinion on this procedure. The Commission took the position that the auditor had not complicd with the requirement that he express an opinion on the accounting practices and procedures followed by the registrant. The accountant thereupon inserted the following statement in his certificate: "We are of the opinion that it would have been preferable to have made such charges against Earned Surplus, and in such event the Earned Surplus and Paid-in Surplus of the registrant would have been $\$ . \ldots \ldots \ldots \ldots$ and $\$ \ldots \ldots \ldots \ldots$ respectively."

supra note 17. 
"Nor is this figure saved by the accompanying disclaimer in the footnote. The footnote itself is deceptively similar to a common form in general use by conservative accountants who wish to make clear that they accept no responsibility for valuations, as lying outside their province. This foornote gives no indication that the net present value, far from being the open question which it suggests, has actually been ascertained, in accordance with proper application of the technique improperly followed, to be definitely less than the amount stated on the balance sheet. The footnote as submitted by no means adequately informs the investor and should not be permitted to protect the registrant. Moreover, even were the footnote to state with complete frankness the true fact that the assets were over-valued, this would not mitigate the effect of the valuation figure itself. A balance sheet item which is flatly untrue will not be rendered true merely by admission of untruth."

The development of the concept of full disclosure exemplified in these cases, even though substantial grounds for distinction may exist, is most significant. But there have been other developments which at least merit mention in connection with financial statements.

In the Haddam Distillers ${ }^{58}$ and Continental Distillers"s cases, the use of "pro forma" balance sheets showing cash on hand from proceeds of the securities to be issued was held misleading when the underwriters were under no firm commitment but merely had an option to take down stock. In the Franco Mining, ${ }^{55}$ LewisAmerican Airways, ${ }^{56}$ American Terminals \& Transit, ${ }^{57}$ and Mining and Development $t^{58}$ cases, the setting up of a lease-hold interest as a fee was held misleading. The failure to calculate the present value of future income in appraising mining property was held misleading in the La Luz Mining, ${ }^{59}$ American Terminals and Transit, and Mining and Development cases. The failure to write off worthless experimental expenses was held misleading in the American Gyro case. ${ }^{\circ 0}$ Many others might be added. Enough has been shown to demonstrate that the investor should benefit from the disclosure of such practices as these. .

\section{Concuuston}

The object of the Act, full disclosure, can be achieved only if basically the statute requires information on matters essential to the exercise of intelligent and sound judgment and if the Commission in administering the Act discovers and applies principles and policies resulting in that disclosure in media and form within the range of understanding of the investing public.

It is quite apparent that the nature and extent of the disclosure accomplished by the administration of the Act exceeds that anticipated by early commentators on the statute. Quite obviously, perfection has not been attained, but the fluidity and adaptability of the administration of the registration provisions of the Act, giving form and content and new meaning to the information required by Schedule $A$, gives increasing encouragement that the Act, even though it falls short of some of its aims, is the first step towards the creation of a more enduring and substantial basis for security selling to the public.

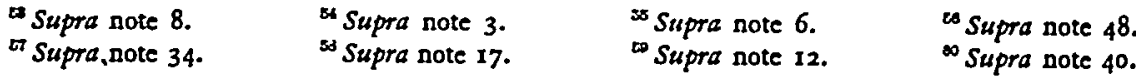


In addition to these basic questions of statutory authority and administrative wisdom, there are other ractors at work which should promote the attainment of the objective. There has been a gradual development of a group of experts, outside as well as inside the Commission, whose knowledge of the Act and familiarity with its requirements make for ease and clarity of presentation of material in a prospectus. At the same time, the Commission in its various rulings and releases, particularly in its findings of fact and opinions, keeps the investing public abreast of and acquainted with the various devices employed to suppress or misrepresent material facts relevant to an appraisal of the value of the securities.

The educational value of these opinions should aid in the development of the intelligent investor. But the requirements of the Act are not based solely on the belief that the investor will learn to protect himself. As in other fields, reliance is placed on the development of independent experts. The investment counsel, the investment department of a bank and the financial advisory services obtain essential information concerning securities with a relatively broad market. This information was hitherto often undisclosed even to powerful institutional and personal buyers. These experts, armed with sufficient information, serve to give the investor new protection. Investment tends to become something less than gambling and more of a process on which intelligence may be brought to bear.

Moreover, the protection of the Securities Act is not the only bulwark for the investor. It is part of a coherent development extending through many years that has endeavored to insure adequate publicity as to corporate affairs. This development is based on the belief that a business which has outgrown a personal character should assume obligations commensurate with its enlarged opportunities as a public enterprise. The listing requirements of stock exchanges, the requirements of state "blue-sky" laws, the regulations of the Interstate Commerce Commission within its jurisdiction, are all instances of this development prior to the Securities Act. The emphasis of the Securities Act is on information in connection with the issuance of a security. That continuing information about securities is desirable is evidenced by the requirements of the Securities Exchange Act of 1934, which helps complete the growing network impelling full disclosure of the facts of corporate enterprise. The significance of the Securities Act must be considered in light of this larger development.

These factors serve to implement the basic mandate of full disclosure embodied in the Act. This mandate will not serve to cure all the intricate problems involved in investment. But the emphasis on the underlying elements in the investment picture has furthered the attainment of desirable objectives. It has aided the investor not only in the prevention of past abuses but also in the clear presentation of the present factors of significance. The data obtained have laid the basis for further legislation in this field. The Act and its administration deserve credit for this threefold attainment. 